International Journal of Business, Economics and Management

2020 Vol. 7, No. 6, pp. 411-426.

$\operatorname{ISSN}(e): 2312-0916$

$\operatorname{ISSN}(p): 2312-5772$

DOI: $10.18488 /$ journal.62.2020.76.411.426

(C) 2020 Conscientia Beam. All Rights Reserved.

check for
updates

\title{
THE IMPACT OF DATA FREQUENCY ON THE LEVEL OF EXCHANGE RATE PASS- THROUGH TO CONSUMER PRICES IN NIGERIA
}

\author{
Babagana Mala \\ Musti
}

\author{
Department of Economics, Faculty of Social \& Management Sciences, Yobe \\ State University, Damaturu, Nigeria. \\ Email:bgrmmusti@ysu.edu.ng.Tel: +2347031964657
}

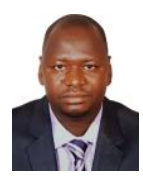

ABSTRACT

Article History

Received: 10 August 2020 Revised: 15 September 2020 Accepted: 30 September 2020 Published: 13 October 2020

Keywords:

Data frequency

Exchange rate

Consumer price.

\section{JEL Classification:}

F31, E31.

\begin{abstract}
This paper investigates the differential impact of data frequency in determining the degree of exchange rate pass-through (ERPT) to consumer prices in Nigeria. The study used annual and quarterly time-series data for 1986- 2013 period. The paper examined the level of long-run ERPT, the speed of adjustments and short-run ERPT using ARDL model. We found high and statistically significant ERPT in the long-run, which is in contrast with the previous studies on Nigeria. The results using quarterly data revealed incomplete ERPT to consumer prices. This paper shows that studies which use higher frequency data are more likely to get incomplete ERPT in the short-run, even in the context of LDCs. In the long-run, incomplete ERPT subsists with the quarterly data while there is a full ERPT for the annual data. The policy implication is that exchange rate stability plays a crucial role in controlling domestic consumer price inflation in Nigeria.
\end{abstract}

Contribution/Originality: This study contributes to the existing literature by using different data frequencies to determine the degree of ERPT in Nigeria. No previous study on Nigeria assesses the impact of the data frequencies on the ERPT.

\section{INTRODUCTION}

This paper examines whether the exchange rate pass-through (ERPT) to consumer prices in Nigeria varies with data frequency. In our empirical analyses, we use annual and quarterly time-series data. There are few empirical studies on Nigerian which provide different results (see, (Aliyu, Yakub, Sanni, \& O., 2009; Zubair, George, \& Sanusi, 2013)). None of these studies examined the issue of whether the degree of ERPT to consumer prices varies with data frequency. Besides, the studies ignore the presence of structural breaks. The objective of this paper is to fill this gap, by investigating the ERPT to prices in Nigeria with quarterly and annual time series data to identify the impact of data frequency. Unlike the previous ones, this study also considers the structural breaks in the data, which improves the model specifications and efficiency of the results.

In the past three-decade, ERPT has been widely studied, especially since the mid-1980s as most developing countries switched from restrictive policies to more liberalisation (See (Aron, Macdonald, \& Muellbauer, 2014; Menon, 1995)). The early studies show that often the exchange rate changes are not entirely transferred to prices of traded goods - the situation which is called an incomplete ERPT in the literature. The early studies suggest that incomplete ERPT were observed in developed countries than in less developed countries(LDCs). They suggest that 
in developing countries, high and complete ERPT were found. Due to the often relatively rigid economic structure in the developing countries, the importing firms are price takers in foreign currency. Therefore all changes in the exchange rate will be transferred to the import prices in home currency (Mallick \& Marques, 2010).

However, as most developing countries switched from the hitherto restrictive policies to liberalisation the research findings of ERPT studies also changed. The incomplete ERPT were now witnessed even in the developing countries (For example, see, (Aliyu et al., 2009; Sanusi, 2010)).

Section 2 of the paper reviews the literature, which includes ERPT studies on Nigeria and the channels of ERPT. The third section explains the theoretical ERPT model and the model used in the empirical analyses. Whereas, Section 4 is the empirical analyses of the observed results. Whereas Section 5 concludes the paper and provides policy recommendations.

\section{LITERATURE REVIEW}

Empirical studies on ERPT to consumer prices in Nigeria provide conflicting, inconsistent, and inconclusive results. The different methodologies, sample periods and data frequency used in the analyses could be the reason for the inconsistencies. Table 1 presents the study on ERPT in Nigeria, showing the methodology, sample periods, data frequency and the outcome of the studies.

Table-1. Typology of studies for Nigeria investigating ERPT.

\begin{tabular}{|c|c|c|c|c|c|c|}
\hline Study & Method & $\begin{array}{l}\text { Sample } \\
\text { periods }\end{array}$ & $\begin{array}{c}\text { Data } \\
\text { frequency }\end{array}$ & $\begin{array}{c}\text { Break } \\
\text { considered? }\end{array}$ & $\begin{array}{c}\text { Key } \\
\text { findings }\end{array}$ & Weakness \\
\hline $\begin{array}{l}\text { Aliyu et al. } \\
\text { (2009) }\end{array}$ & VECM & $\begin{array}{l}1986 Q_{1}- \\
2007 Q^{4}\end{array}$ & $\begin{array}{c}\text { Quarterly } \\
\text { data }\end{array}$ & $\begin{array}{l}\text { No } \\
\text { breakpoint }\end{array}$ & $\begin{array}{c}\text { Low } \\
\text { ERPT }\end{array}$ & $\begin{array}{c}\text { Ignored } \\
\text { breakpoints and } \\
\text { only quarterly data } \\
\text { used. }\end{array}$ \\
\hline $\begin{array}{c}\text { Adeyemi and } \\
\text { Samuel (2013) }\end{array}$ & VECM & $\begin{array}{l}1970- \\
2008\end{array}$ & Annual data & $\begin{array}{c}\text { No } \\
\text { breakpoint }\end{array}$ & $\begin{array}{c}\text { Incomplete } \\
\text { High(O.83) } \\
\text { ERPT }\end{array}$ & $\begin{array}{c}\text { Ignored } \\
\text { breakpoints and } \\
\text { only quarterly data } \\
\text { used. }\end{array}$ \\
\hline $\begin{array}{c}\text { Bada et al. } \\
(2016)\end{array}$ & VECM & $\begin{array}{c}1995 \mathrm{Q} 1- \\
2015 \mathrm{Q}^{1}\end{array}$ & $\begin{array}{c}\text { Quarterly } \\
\text { data }\end{array}$ & $\begin{array}{c}\text { No } \\
\text { breakpoint }\end{array}$ & $\begin{array}{c}\text { Incomplete } \\
\text { low }(0.24) \\
\text { ERPT }\end{array}$ & $\begin{array}{c}\text { Ignored } \\
\text { breakpoints and } \\
\text { only quarterly data } \\
\text { used. }\end{array}$ \\
\hline $\begin{array}{c}\text { Oriavwote and } \\
\text { Omojimite } \\
(2012)\end{array}$ & VECM & $\begin{array}{l}1970- \\
2009\end{array}$ & Annual data & $\begin{array}{c}\text { No } \\
\text { breakpoint }\end{array}$ & $\begin{array}{l}\text { Long-run } \\
\text { relationship } \\
\text { exists }\end{array}$ & \\
\hline $\begin{array}{l}\text { Oyinlola and } \\
\text { Egwaikhide } \\
\text { (2011) }\end{array}$ & VECM & $\begin{array}{l}1980- \\
2008\end{array}$ & Annual data & $\begin{array}{c}\text { No } \\
\text { breakpoint }\end{array}$ & $\begin{array}{l}\text { Long-run } \\
\text { relationship } \\
\text { exists }\end{array}$ & $\begin{array}{l}\text { Ignored } \\
\text { breakpoints and } \\
\text { only annual data } \\
\text { used. }\end{array}$ \\
\hline $\begin{array}{l}\text { Usman and } \\
\text { Musa (2018) }\end{array}$ & VECM & $\begin{array}{c}1960- \\
2015\end{array}$ & Annual data & $\begin{array}{c}\text { No } \\
\text { breakpoint }\end{array}$ & $\begin{array}{l}\text { Significant } \\
\text { ERPT }\end{array}$ & $\begin{array}{l}\text { Ignored } \\
\text { breakpoints and } \\
\text { only annual data } \\
\text { used. }\end{array}$ \\
\hline $\begin{array}{l}\text { Zubair et al. } \\
\qquad(2013)\end{array}$ & SVAR & $\begin{array}{l}1986- \\
2010\end{array}$ & $\begin{array}{c}\text { Quarterly } \\
\text { data }\end{array}$ & $\begin{array}{c}\text { No } \\
\text { breakpoint }\end{array}$ & $\begin{array}{l}\text { Incomplete, } \\
\text { low(O.2) and } \\
\text { fairly slow) } \\
\text { ERPT in } \\
\text { the long- } \\
\text { run }\end{array}$ & $\begin{array}{c}\text { Ignored } \\
\text { breakpoints and } \\
\text { only quarterly data } \\
\text { used. }\end{array}$ \\
\hline
\end{tabular}

All the studies presented in Table 1 used VECM except Zubair et al. (2013). This shows that almost all the studies found a long-run ERPT as VECM is used only when at least one cointegration is established. All the studies show incomplete ERPT, though some show high Whereas others found low ERPT. The three studies that used 
quarterly data: Aliyu et al. (2009); Bada et al. (2016); Zubair et al. (2013) reported low ERPT. The remaining four studies that used annual data found higher ERPT.

The studies covered different periods; however, almost all covered the 1990 s and 2000 s when Nigeria witnessed significant exchange rate fluctuations, consumer price inflation and exchange rate policy changes. Nevertheless, none of the studies allows structural breaks in their analysis. To recognize the presence of the regime shifts is vital as ignoring structural breaks could create to wrong model estimation and misdiagnosis.

None of the studies presented in Table 1 used more than one data frequency to investigate the potential impact of the data frequency on the ERPT. The inconsistent and inconclusive findings of the existing literature also can be caused by the different data frequencies used by various studies. This study, therefore, investigates the ERPT in Nigeria considering the structural breaks in the data. We also use both the quarterly and annual data in our analyses to examine whether the direction and magnitudes of ERPT to prices differ because of the use of different data frequencies.

\subsection{Channels of Exchange Rate Pass-Through}

The changes in the exchange rate affect domestic prices via two channels, direct and indirect.

\subsection{Direct Channel}

The changes in exchange rate influence domestic consumer prices directly through the impact on the import price of raw material, capital goods and finished goods imported from abroad. When the domestic currency strengthens import prices of the inputs and finished goods will fall. On the other hand, when the local currency weakens the import prices of the foreign inputs and finished goods will rise. Either way, the impact is finally transferred to consumer prices. When the local currency weakens, it will encourage the importation of input which will raise the marginal cost which would, ultimately increase the prices of domestic goods (Hyder \& Shah, 2004).

\subsection{Indirect Channel}

The indirect channel of ERPT is through impact on changes in the demand pattern and the wages, and inflation expectations (Aliyu et al., 2009; Taylor, 2000). The ERPT will be higher when changes in the exchange rate are perceived to be continuous, and the prices will change because of the public expectations (Taylor, 2000).

In the same way, the change in the exchange rate will affect the domestic prices indirectly due to competition in the international market. If the local currency weakens, the price of locally produced goods will drop, which will make the goods relatively cheaper to foreign consumers. The decrease in price will promote export which will ultimately raise the aggregate demand which will also increase the domestic prices (Hufner \& Schroder, 2002).

Different factors influence the speed and level of ERPT (Hyder \& Shah, 2004). However, the main factors that determine the degree of ERPT include market size and competition in the domestic market. If the market for the product is very competitive, the importing firms will be compelled to absorb some amount of the change in the exchange rate to avoid loss of market share. When the market is competitive and heterogeneous the domestic consumers a lot of substitutes, it makes the consumer price sensitive. Conversely, if the industry is restricted, and monopolistic, the import prices tend to be, relatively less reactive to the exchange rate changes, therefore, the ERPT will be higher (Knetter, 1994).

\section{DATA AND METHODOLOGY}

\subsection{Data Sources and Descriptions}

The paper uses both annual and quarterly data from 1986 to 2013 for all variables. The nominal exchange rate (er), consumer price index (2010 base year), U.S. producer price index proxied the importers' cost. Nigerian real GDP (y), and U.S. real GDP which represent local and foreign demand pressure respectively are collected from the 
World Bank's database. The oil price series is derived from the OPEC basket price. The consumer price index (cpi) represents the cost to an average consumer of goods and services. The nominal exchange rate (er) is Naira/U.S. Dollar exchange rate. Oil prices (Oilp) are quarterly and annual average prices of the OPEC reference basket. D95 a dummy which takes one from 1995 to 1998 and zero otherwise. The dummy represents the four years of the fixed exchange system in the 1990s in Nigeria.

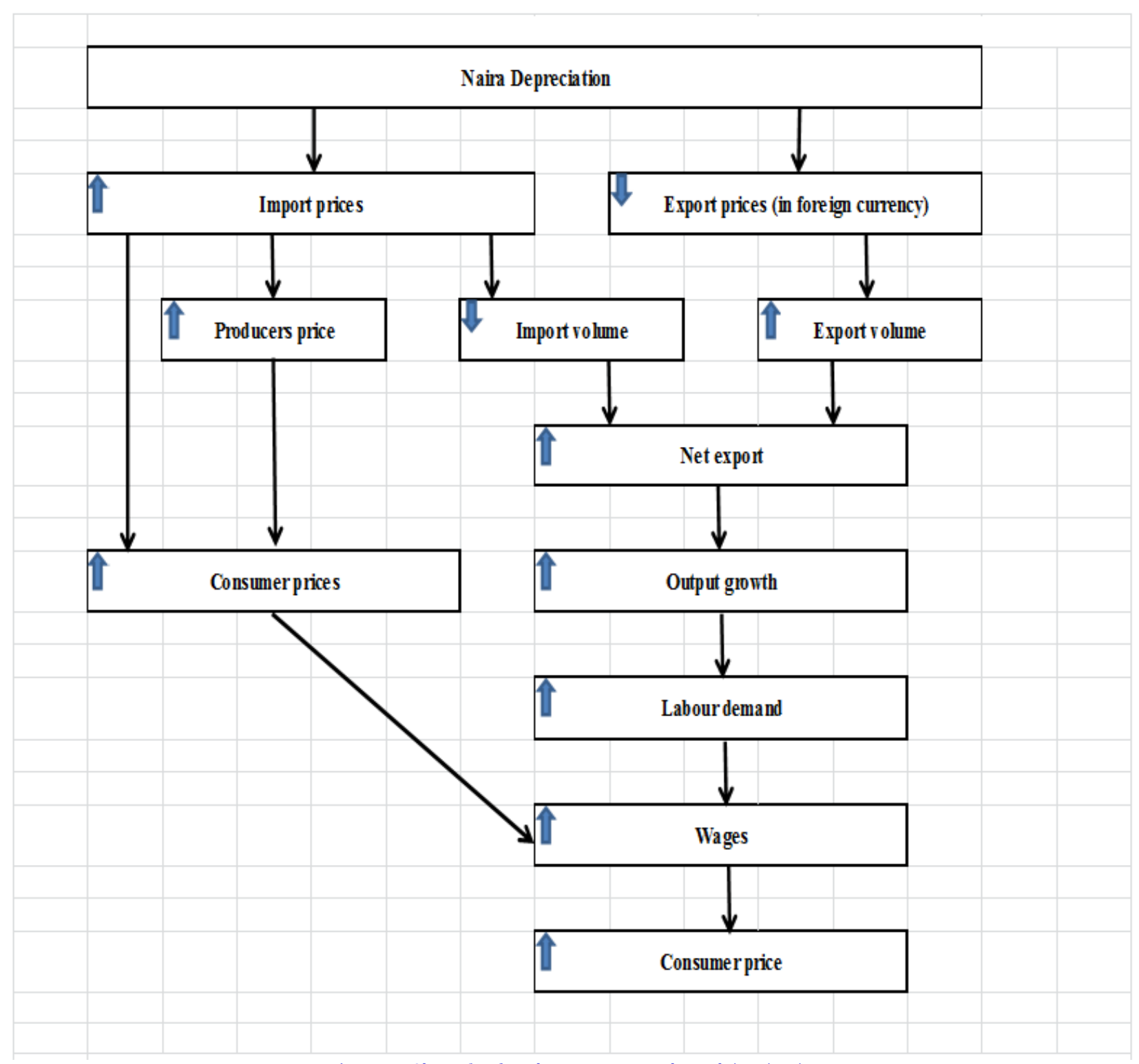

Figure-1. Channels of Exchange rate pass-through in Nigeria.

Note: The arrows connection the boxes show causality, while the arrows inside the boxes indicate the direction of change of the variable. Source: Laflèche (1997).

\subsection{Theoretical ERPT Model}

Following Campa and Goldberg (2005) model on ERPT, this paper adopts a micro-based partial equilibrium mark-up model which incorporates some general equilibrium aspects at aggregate price levels. We extend the model by including the impact of domestic costs of the importing country. The import price $\mathrm{P}_{\mathrm{m}}$ of a nation can be presented as

$P_{m}=P_{x} / E$ 
Where $P_{x}$ is the price of the exporter and $\mathrm{E}$ is the exchange rate. The $\log$ linearisation of Equation 1 gives $^{1}$ :

$p_{m}=p_{x}-e$

The exporter's prices $P_{x}$ is expressed as a mark-up (MU $)$ over the exporter's marginal costs $\mathrm{MC}_{\mathrm{x}}$.

$$
P_{x}=M U_{x} M C_{x}
$$

The $\log$ transformation of Equation 3, i.e. $p_{x}=m u_{x}+m c_{x}$ and the substituting it into Equation 2 gives:

$$
p_{m}=m u_{x}+m c_{x}-e
$$

Assuming there is an inverse relationship between the mark-up is and the price elasticity of demand in the local market and relies on the pattern of the demand curve. The mark-up is a function of the demand pressure and real exchange rate. The link between the real exchange rate and the mark-up is depicted with the effect of import costs in the exporting country $\left(\boldsymbol{w}_{x}\right)$ and simplified in log linearised form as follows:

$$
m u_{x}=\mu+\varphi\left(e-w_{x}\right)
$$

$\varphi$ lies between 0 and 1 . If $\varphi=0$ it implies producer currency pricing $(\mathrm{PCP})$, meaning change in exchange rate does not affect the price. Whereas if $\varphi=1$, it implies local currency pricing (LCP) meaning the change in the exchange rate is fully transferred to the price with on effect on the mark-up assuming the marginal costs are fixed. The $\mu$ in Equation 5 stands for constant. To make it simpler, Equation 5 eliminates the effect of other factors, like demand pressure in the local economy. The Equation 6 is a $\log$ linearised form: assuming the exporter's marginal costs increases by a weighted average of market wage $w_{x}$; with other prices such as oil prices, poil $x$, and the demand pressure in the exporting country, $y_{x}$, and the demand pressure in the local market, $y_{m}$.

$$
m c_{x}=\partial_{1} w_{x}+\left(1-\partial_{1}\right) p o i l_{x}+\partial_{3} y_{x}+\partial_{4} y_{m}
$$

In Equation 6 depict import prices at the point of entry to the end country, before the additional costs of distribution and home taxes.

$p_{m}=\mu-(1-\varphi) e+\partial_{1} w_{x}+\left(1-\partial_{1}\right) p o i l_{x}+\partial_{3} y_{x}+\partial_{4} y_{m}$

Equation 7 presents the long-run model after adding the end country's local costs into the mark-up function, and cost of exogenous goods into the exporter's marginal cost function.

The long-run ERPT coefficient is $\beta=-(1-\varphi)$, representing the exchange rate elasticity of import prices. If $\varphi=0$ then $\beta=-1$, implying producer currency pricing (PCP). This shows a one-for-one relationship between the import price and the exchange rate hence, there is a full ERPT. On the other hand, if $\varphi=1$, and $\beta=0$, then, it implies zero ERPT to prices. Therefore, it means the use of local currency pricing (LCP), here the exporters completely absorb all the changes in exchange rate by reducing their profit margin, to maintain a constant price. A log-linear regression for the long-run ERPT to import prices is depicted in Equation 8:

$$
p_{m t}=\lambda+\eta e_{t}+a_{1} w_{x t}+a_{2} p o i l_{x t}+a_{3} y_{x t}+a_{4} y_{m t}+\varepsilon_{t}
$$


where $p_{m}$ is the import price in home currency, $\lambda$ stands for a constant, e represents (nominal) exchange rate, $w_{x}$ represents exporter costs, poil $_{x}$ represents an additional aspect of exporter's costs from commodity prices, such as oil prices, and $y_{x}$ and $y_{m}$ are stand for demand in the foreign market and the home market.

Equation 8 depicts the ERPT to import price (Stage 1 ERPT). According to Aron et al. (2014), Stage 2 ERPT of import prices to consumer prices, is a "weighted combination of import price ERPT to producer prices, and producer price ERPT to consumer prices". swapping the import prices into a producer prices equation, and then substituting the producer prices into a consumer prices equation eliminates the import prices and the producer prices. The ensuing reduced-form Equation for general ERPT would be similar to Equation 8. However, the coefficients are not the same. Hence, the overall ERPT to consumer prices is as in Equation 9:

$p_{\text {cpi } t}=\lambda+\eta e_{t}+a_{1} w *_{x t}+a_{2} p o i l_{x t}+a_{3} y_{x t}+a_{4} y_{m t}+\varepsilon_{t}$

where $p_{c p i, t}$ is the consumer price. In the next section, we specify our empirical model based on the theoretical model explained in this section.

\subsection{Empirical Model Specification}

Following our theoretical model developed in section 10 above, a five-variable Autoregressive distributed-lag model (ARDL) to examine the short-run and long-run ERPT is explained below:

$x_{t}{ }^{\prime}=\left(c p i_{t}, e r_{t}, p p i_{t}, o i l p_{t}, y_{t}\right)$

Where $c p i$ denotes the consumer prices, er denotes the nominal exchange rate, $p p i_{t}$ is producer price index which proxied the importers' cost, oil $p_{t}$ is the oil prices and $y_{t}$ is domestic real GDP. All variables in Equation 10 are in logarithms. We included the D(95) dummy variable and U.S. real gross domestic product (f_y ) as (fixed) regressors. D(95) included capturing the fixed exchange rate regime between 1994 and 1998 in Nigeria. U.S. real gross domestic product ( $f_{-} y$ ) is also included to control for foreign demand pressure.

In the next section, we test the stationarity of the variables used in the study to ascertain their order of integration.

\section{RESULT AND DISCUSSION}

\subsection{Unit Root Test}

We test for the presence of unit root in the time series to determine the order of integration of the variables. It is vital in time series analysis to verify the properties of the data generation process, especially when modelling long-run relationship to avoid spurious regression. Spurious regression produces a statistically significant long-run relationship in the form of contemporaneous correlations.

As highlighted above, the existing studies on Nigeria ignored the breaks in the series. Augmented DickeyFuller (ADF) unit root test often accepts the null of a unit root though a trend is included in the ADF regression. It happens when a data is stationary around a deterministic trend and there is a structural break (Perron, 1989; Zivot $\&$ Andrews, 1992). The unit root test is also less powerful when a series presents a shift in the intercept. However, where the breaks dates are known, the ADF test can be modified to include dummy variables in the ADF regression (Joyeux, 2001). Perron (1989) specified an a priori fixed break date. Later studies (Banerjee \& Russell, 2001; 
Vogelsang \& Perron, 1998; Zivot \& Andrews, 1992) concentrated on endogenously identifying break dates from the data. Hence, we conducted the unit-roots test employing a modified augmented Dickey-Fuller test (Perron, 1989).

Table-2. Unit root test.

\begin{tabular}{|c|c|c|c|c|c|}
\hline \multicolumn{6}{|c|}{ H1: I(0) Ho: I(1) } \\
\hline \multicolumn{6}{|c|}{ Annual data (1986-2017) } \\
\hline & lcpi & ler & ly & loilp & lppi \\
\hline Levels & $-11.196^{*}$ & $-6.063^{*}$ & $-5.689^{*}$ & $-5.669^{*}$ & -2.653 \\
\hline First Differences & & & & & $-5.17 *$ \\
\hline \multicolumn{6}{|c|}{ Quarterly data (1986Q4-2013Q4) } \\
\hline & lcpi & ler & ly & loilp & lppi \\
\hline Levels & $-8.075^{*}$ & $-5.434^{*}$ & $-5.249^{*}$ & $-5.27^{*}$ & $-7.480^{*}$ \\
\hline First Differences & & & & & \\
\hline
\end{tabular}

Table 2, shows that all variables with both quarterly and annual data are stationary at levels, except lppi, which non-stationary with the annual data. Given that not all variables are I(0), we examine the causal relationships in long-run and short-run between consumer price and exchange rate and the other variables applying the Bounds testing procedure.

\subsection{Granger Causality}

We conducted a Granger causality test by testing the null hypotheses of $\boldsymbol{X}$ does not Granger-cause $\boldsymbol{Y}$ and vice versa. When the null hypotheses are rejected in both cases, it means there is Granger causality. The Granger causality test results in Table 3 show that there is a one-directional Granger causality from exchange rates to consumer prices. This is a justification for the use of the exchange rate as the dependent variable in the ARDL model. There is also a unidirectional Granger causality from consumer prices to the oil price. However, there is no significant Granger causality between import cost and consumer prices.

Table-3. The Granger causality test.

\begin{tabular}{|c|c|c|c|}
\hline \multicolumn{3}{|l|}{ Sample: 1986 -2013. Annual Data } & \multirow[b]{3}{*}{ Prob. } \\
\hline \multicolumn{2}{|l|}{ Lags: 2} & \multirow[b]{2}{*}{ F-Statistic } & \\
\hline Null Hypothesis: & Obs & & \\
\hline LER does not Granger Cause LCPI & 28 & $3.2059^{*}$ & 0.0591 \\
\hline \multicolumn{2}{|l|}{ LCPI does not Granger Cause LER } & 2.53358 & 0.1013 \\
\hline LOILP2 does not Granger Cause LCPI & 28 & 0.01196 & 0.9881 \\
\hline \multicolumn{2}{|l|}{ LCPI does not Granger Cause LOILP } & $3.31288^{*}$ & 0.0544 \\
\hline LGDP does not Granger Cause LCPI & 28 & 0.64831 & 0.5322 \\
\hline \multicolumn{2}{|l|}{ LCPI does not Granger Cause LGDP } & 2.52872 & 0.1017 \\
\hline LPPI does not Granger Cause LCPI & 28 & 0.10974 & 0.8965 \\
\hline \multicolumn{2}{|l|}{ LCPI does not Granger Cause LPPI } & 0.43379 & 0.6532 \\
\hline
\end{tabular}

Note: * Significance at the $10 \%$ level.

\subsection{Test of Cointegration Using Autoregressive Distributed-lag (ARDL) Bounds Testing Approach}

Autoregressive distributed-lag (ARDL) models are extensively used in the studies of a long-run relationship where series are integrated of level I(1) (Giles, 2013). If the series is I(1), the Ordinary Least Squares (OLS) shortrun estimators are the consistent square root of the sample size (Pesaran \& Shin, 1999). The Pesaran., Shin, and Smith (2001) bound testing method uses $F$ and $t$-statistics to check the significance of the lagged levels of the variables in a univariate error correction system as it is inexact whether is a trend or integrated of order 1 . The Pesaran. et al. (2001) bound testing method can include both $\mathrm{I}(0)$ and $\mathrm{I}(1)$ variables in the analyses and outperforms 
other cointegration tests with small sample size. To enhance the interpretability of the coefficients of our model and to deal with the problem of outliers and ensure that the variables are normally distributed, we included deterministic terms like intercept and time trends in our modelling.

As can be seen in Table 2, the variables are not integrated in the same order as the producer price index is $\mathrm{I}(1)$ Whereas other variables are $\mathrm{I}(\mathrm{O})$. Therefore, this study employs the ARDL to investigate the long-run and shortrun dynamics of the model and test for the presence of cointegration. The ARDL is appropriate whether the variables are trend stationary or difference stationary (Pesaran \& Shin, 1999). According to Engle and Granger (1987) when the level of $\mathrm{I}(1)$ series are constrained by a cointegrating relationship, the data generating process will be described as an error correction model (ECM). Though, at one level an ECM is essentially one likely (constrained) parameterisation of a vector autoregression (VAR). Given that each Equation of a VAR is an autoregressive distributed lag (ARDL) regression then the representation theorem could be considered as signifying that cointegrating relationships, and short-run dynamics, can be examined by estimation of ARDL regressions. According to Pesaran and Shin (1999) un-modified OLS has important asymptotic properties when applied to ARDL if the lag lengths are enough to proxy for the autocorrelation and endogeneity.

Furthermore, Pesaran and Shin (1999) added that the choice of an estimator for small-sample analysis ought to be built on Monte Carlo assessment and present proof to justify a "two-step" approach. The lag lengths are initially decided with Akaike information criterion or Schwartz Bayesian criterion and OLS applied to the ARDL model specifying the short-run dynamics. The identification of the coefficients of the ECM or the long-run model follows as a reparameterisation process.

Pesaran, Shin, and Smith (1996) suggested a technique for identifying the explained variable in a system with one cointegrating relationship. The technique comprises of the calculation of tests of standard hypothesis, although with unusual critical values, used in an unrestricted version of an ECM (UECM), as follows:

$$
\Delta y_{t}=\sum_{1} \alpha_{i} \Delta y_{t-i}+\sum_{0} \beta_{i}^{\prime} \Delta x_{t-i}+\Phi y_{t-1}+\delta^{\prime} x_{t-1}
$$

The joint hypothesis $\Phi=0, \delta^{\nabla}=0$ assert the non-existence of ECM and thus no long-run relationship. An "F-statistic" of this proposition is conducted with non-standard critical values introduced by Pesaran et al. (1996) reported in Table 5. The UECM is normalised on certain dependent variables by ignoring the current change; using the F-test for all similar normalisations creates a check for the direction of causality.

As defined above, this paper follows a two-step method to estimate the ARDL form of Equation 11. Firstly, a 'stability tests' is conducted to examine the presence of the long-run relationship, between the variables cpi, er, ppi, oilp and gdp. Dummy D95 is considered an exogenous variable. The following UECM is built with cpi as the dependent variable:

$$
\begin{aligned}
\Delta c p i_{t}=\alpha_{y 0} & +\alpha_{y 95} D 95+\sum_{i=1}^{n} b_{y i} \Delta_{i} c p i_{t-i}+\sum_{i=0}^{n} c_{y i} \Delta_{i} e r_{t-i}+\sum_{i=0}^{n} d_{y i} \Delta_{i} p p i_{t-i} \\
& +\sum_{i=0}^{n} e_{y i} \Delta_{i} \text { oilp } p_{t-i}+\sum_{i=0}^{n} f_{y i} \Delta_{i} \text { oil } p_{t-i}+\gamma_{1 y} c p i_{t-1}+\gamma_{2 y} e r_{t-1}+\gamma_{3 y} p p i_{t-1} \\
& +\gamma_{4 y} \text { oilp }_{t-1}+\gamma_{5 y} g d p_{t-1}+\varepsilon_{t}
\end{aligned}
$$

Since there is a restricted number of observations, the maximum lag, $\mathrm{n}$, is specified as 4 . The $\mathrm{F}$ test, represented by $F_{c p i}\left(c p i \| e r_{,} p p i, o i l p, g d p\right)$, is applied to check the presence of a 'stable and long-run relationship' when 
$c p i$ is considered as a dependent variable and $e r, p p i$, oilp, and $g d p$ are considered as independent variables. The null hypothesis that the coefficients of all level variables are jointly zero can be expressed as: $H_{0}: \gamma_{1 y}=\gamma_{2 y}=\gamma_{3 y}=\gamma_{4 y}=\gamma_{5 y}=0$. The alternative hypothesis is $H_{1}: \gamma_{1 y}, \gamma_{2 y}, \gamma_{3 y}, \gamma_{4 y}, \gamma_{5 y} \neq 0$.

A dummy variable D95² was also included in the equation to represent the structural breaks due to the fixed exchange regime adopted between 1994 and 1998. Nigeria adopted a managed floating exchange rate system in 1986. Nevertheless, eight-year on in 1994 up to 1998 the government was compelled to peg the Naira to U.S. dollar. The policy objective was to stabilise the Naira exchange rate and stop the rising inflation because of the constant depreciation of the Naira which was passing through to domestic consumer prices. This was due to the excessive depreciation of the Naira and the impact on the consumer prices which led to the record high consumer prices inflation rates $(70 \%)$ in 1993 . The fixed system was left in 1998 with a return to managed floating exchange rates.

The inclusion of the shift dummy in Equation 2 is important as unacknowledged structural breaks could result in mis-specification bias in the estimation of the equation and misdiagnosis the properties of the time-series. Gregory-Hansen cointegration test was used to check the robustness of our findings with the dummy to confirm the existence of a structural break around the same period.

Table-4. The Quandt-Andrews unknown breakpoint test.

\begin{tabular}{c|c|c|c}
\hline Statistic & Breakpoint date & Value & Prob. \\
\hline LR F-statistic & $\left(1995 Q^{2}\right)$ & 192.1648 & $0.0000^{*}$ \\
\hline Wald F-statistic & $\left(1995 Q^{2}\right)$ & 960.8238 & $0.0000^{*}$ \\
\hline Note: *ignificance at the $5 \%$ level.
\end{tabular}

We used Quandt-Andrew unknown breakpoint test to compute the constancy of parameter. Table 4 shows the results of the Quandt-Andrew unknown breakpoint test. The result in Table 4 confirms the existence of a structural break at 1995Q4 in the exchange rate series and this break consistent with the introduction of the fixed exchange rate implemented in 1994-1998. Our Gregory-Hansen cointegration test confirms the breakpoint in 1993 (See Appendix 1.2.2). No significant break is observed in all other series. The break in the exchange rate confirms the start of the fixed exchange rate system of the mid-1990s in the country.

We applied (Pesaran \& Shin, 1999) 'Bounds Test' to determine the cointegration for applying an errorcorrection restriction on the coefficients of the ARDL model. Pesaran and Shin (1999) upper bounds for the critical values are used if all our variables are $I(1)$ while lower bounds apply if none of our variables is $I(1)$. Our variables comprise of $I(0)$ and $I(1)$; hence, the asymptotic critical values will be unknown however it lies within the known upper and lower bounds.

In Table $5, F$-statistic $(F=14.837)$ for the annual data significantly surpasses the upper bound of the critical value (4.37) at a $1 \%$ significance level. Hence, we reject the hypothesis of 'There is no long-run relationship' so there is a long-run cointegrating relationship among the variables in levels, with the $c p i$ as a dependent variable and

er, $p p i$, oilp, and $g d p$ are considered as independent variables. However, the reported $F$-statistic $(F=2.26)$ for the quarterly data is less than lower bound (2.45) of the critical value at a $10 \%$ significance level for which we could not reject the hypothesis of 'There is no long-run relationship'.

A maximum number of lags of 4 is used for the ARDL model estimation. The best model based on SIC has an $R^{2}$ value of 0.99 . The test for autocorrelation shows no statistically significant serial correlation of the residuals (see Appendix 1).

${ }^{2}$ A dummy variable (D95) captures structural breaks in the exchange rate series. This dummy takes a value of 1 after $1995(2)$ and 0 otherwise. 
Table-5. F-Bounds Test

\begin{tabular}{|c|c|c|c|c|}
\hline \multicolumn{5}{|c|}{ Quarterly Data (1986Q4-2013Q4) } \\
\hline \multicolumn{2}{|c|}{ F-Bounds Test: $F_{c p i}\left(c p i \mid e r_{,} p p i\right.$, oilp, gdp) } & \multicolumn{3}{|c|}{ Null Hypothesis: No levels relationship } \\
\hline Test Statistic & Value & Significance level. & $\mathrm{I}(0)$ & $\mathrm{I}(1)$ \\
\hline F-statistic & 2.26 & $10 \%$ & 2.45 & 3.52 \\
\hline \multirow[t]{3}{*}{ K } & 4 & $5 \%$ & 2.86 & 4.01 \\
\hline & & $2.5 \%$ & 3.25 & 4.49 \\
\hline & & $1 \%$ & 3.74 & 5.06 \\
\hline \multicolumn{5}{|c|}{ Annual Data (1986 - 2013) } \\
\hline \multicolumn{2}{|c|}{ F-Bounds Test: $F_{c p i}\left(c p i \mid e r_{,} p p i\right.$, oilp, gdp) } & \multicolumn{3}{|c|}{ Null Hypothesis: No levels relationship } \\
\hline Test Statistic & Value & Significance level. & $\mathrm{I}(0)$ & $\mathrm{I}(1)$ \\
\hline F-statistic & 14.83 & $10 \%$ & 2.2 & 3.09 \\
\hline \multirow[t]{3}{*}{$\mathrm{K}$} & 4 & $5 \%$ & 2.56 & 3.49 \\
\hline & & $2.5 \%$ & 2.88 & 3.87 \\
\hline & & $1 \%$ & 3.29 & 4.37 \\
\hline
\end{tabular}

Table 6 shows the ECM estimation result of the best model where ' $\mathrm{D}(\mathrm{X})$ ' is the variable $\mathrm{X}$ 's first difference and ' $\mathrm{D}(\mathrm{X}(-\mathrm{n}))^{\prime}$ lags the variable X's first difference by $n$ years. The error-correction coefficients are negative (-0.020) and (-0.338) for the quarterly and annual data respectively and are statistically significant. This confirms a cointegrated stable long-run relationship. The coefficients are very small, implying slow adjustments. The speed of adjustments for annual data is higher than that for the quarterly data. This also shows that in the annual data the period is long enough for all potential rigidities to be relaxed than the quarterly data.

These results reveal that exchange rate (er), producer price (ppi), oil price (oilp) and GDP (gdp) are cointegrated with cpi as the dependent variable. Hence, the main long-run determinants of cpi are er, ppi, oilp and GDP.

We run the estimation for the Equation 8 specifications and only statistically significant coefficients are reported /included in Table 6. Our results reveal that there is a statistically significant short-run impact of changes in the exchange rate on the consumer price with the annual data. However, no statistically significant impact of exchange rate changes on consumer price is observed with the quarterly data. The impact of the exchange rate change on the consumer price (ERPT) is only 0.24 (24\%) even in the annual data that is statistically significant in the short run. The lack of significant impact of the exchange rate on the consumer price in the quarterly data reflects the role of 'market share objectives' and 'menu cost' on transferring the changes in exchange to the price by the importing firms. If the change in the exchange rate could be absorbed by the profit margins of the importing firms, they would not pass-through the exchange rate changes to the prices to avoid market share loss. Similarly, when the exchange rate changes are not large enough to warrant the cost of menu change the importing firms would be reluctant to pass-through the exchange rate changes to the consumer prices. The importing firms adopt a wait-and-see policy when exchange rates are unstable as in Nigeria. They would not immediately transfer the exchange rate change to the prices. This is because some of the exchange rate changes are transitory and not permanent. Hence the three months (quarter) period might not be long enough for the ERPT to take effect due to all these rigidities. However, in the one year, all those rigidities could be resolved and the ERPT could take effect. Hence, the potential higher ERPT in the annual data compared to the quarterly data. This clearly shows the impact of data frequency on the level of ERPT. Results that exchange impact on consumer price is in line with studies like Aliyu et al. (2009) and Zubair et al. (2013).

The producer price which proxies the importer's cost is statistically significant in the short run only with the annual data. Here also, the three months (quarter) may not be long enough for the pass-through to take effect due to the rigidities. However, the significant impact in the annual data shows that within the one year all the rigidities would have been resolved. 
Similarly, the coefficient of oil a price with annual data is 0.65 and is statistically significant, but with an unexpected sign, in the short run. However, this short-run negative effect of oil prices is not surprising, Nigeria being an oil-producing country. Therefore, the oil price does not just form part of import cost, but also affect the demand for the imported goods in the economy. Considering that the increase in oil price implies a rise in foreign exchange earnings for Nigeria.

The coefficients of GDP are statistically significant in both the annual and quarterly data and have expected negative signs in both cases. Any change (increase or decrease) in the GDP reflects in the money circulation and in the hands of the firms, individual households, and government. Hence, the impact on the consumer price would be witnessed quickly compare to the impact of the other variables in our Equation on the consumer price. Therefore, the impact is significant even in the quarterly data.

The estimated ARDL model reported in Table 6 shows the long-run impact of the exchange rate change and other variables on the consumer price. However, the coefficient of the error correction process lagged deviation from equilibrium, ' $\mathrm{E}(-1)$ ', is 0.020 for the quarterly data Whereas 0.338 for the annual data. The estimated coefficients are statistically significant and negative in both cases, implying the presence of the stabilising error correction process. Since there is a stable steady state, we can effectively deliberate the consequences of any persistent combination of the variables exchange rate, producer price, oil price and the GDP on the consumer price.

Table 7 reports estimated long-run model using the annual data to assess the impact on consumer price (cpi) of er, ppi, oilp and GDP. All four estimated coefficients are statistically significant. Conversely, the estimate of the long-run model with the quarterly data revealed that the coefficients of the exchange rate and oil price are statistically significant at $5 \%$ level, Whereas the coefficients of producer price and the GDP are statistically insignificant at $5 \%$ level. This confirms the presence of ERPT in the long-run and the important impact of the oil price on the consumer price in Nigeria. We found high (0.85) and full (1.19) for the quarterly and annual data respectively. These results contradict some of the previous studies, especially those that used quarterly data such as Aliyu et al. (2009) and Bada et al. (2016) who reported low ERPT. The policy implication here is that the government should adopt policies that stabilise the exchange rate. Furthermore, there is a necessity to diversify the economy to reduce the impact of the oil price on consumer prices in the economy. Such policies could reduce the level ERPT to consumer prices.

Table-6. ARDL error correction regression.

\begin{tabular}{|c|c|c|c|c|}
\hline \multicolumn{5}{|c|}{ Quarterly data $\left(1986 Q^{4}-2013 Q^{2}\right)$} \\
\hline Variable & Coefficient & Std. Error & t-Statistic & Prob. \\
\hline $\mathrm{D}(\mathrm{cpi}(-1))$ & 0.680560 & 0.061408 & 11.08261 & 0.0000 \\
\hline $\mathrm{D}(\mathrm{gdp})$ & 0.221043 & 0.181766 & 1.216087 & 0.2271 \\
\hline $\mathrm{D}(\operatorname{gdp}(-1))$ & -0.384283 & 0.178110 & -2.157557 & 0.0336 \\
\hline D_1998Q2 & -0.024607 & 0.007548 & -3.259823 & 0.0016 \\
\hline CointEq(-1) & -0.020256 & 0.004049 & -5.002854 & 0.0000 \\
\hline \multicolumn{5}{|c|}{ Annual data $(1986-2013)$} \\
\hline Variable & Coefficient & Std. Error & t-Statistic & Prob. \\
\hline $\mathrm{D}(\operatorname{cpi}(-2))$ & -0.138260 & 0.102376 & -1.350522 & 0.2138 \\
\hline $\mathrm{D}(\operatorname{cpi}(-3))$ & 0.828985 & 0.080765 & 10.26414 & 0.0000 \\
\hline $\mathrm{D}(\mathrm{er})$ & 0.243321 & 0.030237 & 8.047198 & 0.0000 \\
\hline $\mathrm{D}(\mathrm{ppi})$ & 2.213698 & 0.266977 & 8.291704 & 0.0000 \\
\hline $\mathrm{D}(\operatorname{ppi}(-1))$ & 2.847879 & 0.390271 & 7.297178 & 0.0001 \\
\hline $\mathrm{D}(\operatorname{ppi}(-2))$ & 2.248130 & 0.338744 & 6.636661 & 0.0002 \\
\hline $\mathrm{D}$ (oilp) & -0.656845 & 0.049256 & -13.33542 & 0.0000 \\
\hline $\mathrm{D}($ oilp $(-1))$ & -0.090673 & 0.056983 & -1.591221 & 0.1502 \\
\hline $\mathrm{D}($ oilp $(-2))$ & -0.199984 & 0.049262 & -4.059573 & 0.0036 \\
\hline $\mathrm{D}(\mathrm{gdp})$ & -0.149442 & 0.107423 & -1.391148 & 0.2016 \\
\hline $\mathrm{D}(\operatorname{gdp}(-1))$ & -1.558491 & 0.159032 & -9.799871 & 0.0000 \\
\hline $\mathrm{D}(\operatorname{gdp}(-2))$ & -1.198122 & 0.138482 & -8.651854 & 0.0000 \\
\hline $\mathrm{D}(\operatorname{gdp}(-3))$ & -0.633322 & 0.123317 & -5.135708 & 0.0009 \\
\hline CointEq(-1)* & -0.338417 & 0.026520 & -12.76104 & 0.0000 \\
\hline
\end{tabular}


International Journal of Business, Economics and Management, 2020, 7(6): 41 1-426

Table-7. The estimated long-run relationship between LCPI and LER, LPPI, LOILP, LGDP.

\begin{tabular}{|c|c|c|c|c|}
\hline \multicolumn{5}{|c|}{ Quarterly data $\left(1986 Q^{4}-2013 Q^{2}\right)$} \\
\hline Variable & Coefficient & Std. Error & t-Statistic & Prob. \\
\hline er & 0.855518 & 0.280601 & 3.048883 & 0.0030 \\
\hline ppi & 4.379348 & 4.390065 & 0.997559 & 0.3211 \\
\hline oilp & -2.016453 & 0.825717 & -2.442064 & 0.0165 \\
\hline $\operatorname{gdp}$ & 1.446389 & 2.077004 & 0.696383 & 0.4879 \\
\hline \multicolumn{5}{|c|}{$\mathrm{EC}=\mathrm{cpi}-\left(0.8555^{*} \mathrm{er}+4.3793^{*} \mathrm{ppi}-2.0165^{*} \mathrm{oilp}+1.4464^{*} \mathrm{gdp}\right)$} \\
\hline \multicolumn{5}{|c|}{ Annual Data (1986 - 2013) } \\
\hline Variable & Coefficient & Std. Error & t-Statistic & Prob. \\
\hline er & 1.193506 & 0.123839 & 9.637564 & 0.0000 \\
\hline ppi & -6.158926 & 2.239992 & -2.749530 & 0.0251 \\
\hline oilp2 & -1.401541 & 0.418881 & -3.345920 & 0.0101 \\
\hline $\operatorname{gdp}$ & 5.650698 & 1.055606 & 5.353036 & 0.0007 \\
\hline \multicolumn{5}{|c|}{$\mathrm{EC}=\mathrm{cpi}-\left(1.1935^{*} \mathrm{er}-6.1589^{*} \mathrm{ppi}-1.4015^{*} \mathrm{oilp} 2+5.6507^{*} \mathrm{gdp}\right)$} \\
\hline
\end{tabular}

\section{CONCLUSION AND POLICY RECOMMENDATIONS}

This paper to examine the differential impact of data frequency on ERPT to consumer prices in Nigeria. The paper used time series techniques and both the annual and quarterly data for the post-1986 to investigate the impact of data frequency in determining the degree of ERPT.

This paper applied the ARDL model for the estimation. Both the annual and quarterly data are used in our analyses. This is to find the differential impact if any, of data frequency on the degree of ERPT to consumer prices. Our study examines the level of ERPT to consumer prices and the adjustment process in both the short and longrun equilibria. The results reveal that it is statistically significant and full ERPT in the long-run with the annual data and high $(85 \%)$ but not full with the quarterly data. However, the ERPT in the short-run is statistically significant but low (24\%) with the quarterly data and, it is statistically insignificant with the annual data. Therefore, the degree/extent of ERPT to prices vary. It depends on whether quarterly or yearly are used in the analyses. The implication is that a substantial amount of the changes in the exchange rate is pass-through to the consumer price. Hence the persistent consumer price inflation rate witnessed in Nigeria after switching to the floating exchange rate system in 1986. The government/central bank needs to adopt policies that stabilise the exchange rate to avoid persistent inflation rates.

Our results show that quarterly data produce/generate/reflect partial ERPT to consumer prices, compared to the annual data, in which the short-run rigidities are probable to change. Therefore studies with higher frequency data would probably find partial ERPT in the short-run, even in developing countries. In the long-run, incomplete ERPT subsists with the quarterly data, but full for the annual data.

Our empirical results support the market share and menu cost hypotheses for the importing firms. The results suggest that importing firms in Nigeria do not pass-through every exchange rate change by absorbing the resulting change in their reduced profit margin to control/retain their market shares. The importing firms would have to be certain that a change in exchange rates is substantial and significant enough to necessitate a change in price because of the cost of the menu change. The stickiness of prices, i.e. the absence of the ERPT, applies in response to continuous and unstable changes to exchange rates. Nigeria relied so much on oil export as its source of foreign exchange earnings. Consequently, the volatility of the global oil price is transmitted to the foreign exchange market in Nigerian. Hence, the firms prefer to follow a wait and see policy in changing prices, and consequently, the ERPT in the short run becomes weak and slow and often insignificant. However, importing firms decide to pass the changes in the exchange rate when the change is significant and reach a level which makes the changes in prices economically viable in the long-run where firms are unable to absorb the changes in their profit margin.

The policy implications of our empirical findings are that monetary policies will be ineffective in Nigeria because of its relevance in the short run. A floating exchange rate regime as an instrument for price adjustment will not work if the exchange rate changes reflected quickly in the prices. Therefore, there is a need for new policies to 
facilitate the diversification of the economy it improves the contribution of the non-oil sectors to the foreign exchange earnings. Diversification of the supply side of the foreign exchange market will help stabilise the exchange rates and improve the confidence of firms to perceive changes in the exchange rate as permanent and therefore will respond fast.

The exchange rate stability is important in sustaining stable domestic consumer price. The over-dependence of Nigeria on single product foreign exchange earnings needs a review. Every shock in the international oil price Nigeria's foreign exchange supply plummet, and the exchange rate is affected which also reflected on the consumer price in the long-run, through the ERPT. Diversification of the economy is necessary to reduce the over-reliance on the oil sector for foreign exchange earnings to lessen the impact of the international oil price shock transmissions to domestic consumer prices.

Funding: This study received no specific financial support.

Competing Interests: The author declares that there are no conflicts of interests regarding the publication of this paper.

\section{REFERENCES}

Adeyemi, O. A., \& Samuel, E. (2013). Exchange rate pass-through to consumer prices in Nigeria. Journal of Business Management and Applied Economics, 3(4), 1-10.

Aliyu, S. U. R., Yakub, M. U., Sanni, G. K., \& O., D. O. (2009). Exchange rate pass-through in Nigeria: Evidence from a Vector Error Correction Model' MPRA Paper 25053.

Aron, J., Macdonald, R., \& Muellbauer, J. (2014). Exchange rate pass-through in developing and emerging markets: A survey of conceptual, methodological and policy issues, and selected empirical findings. The Journal of Development Studies 5o(1), $101-143$

Bada, A. S., Olufemi, A. I., Tata, I. A., Peters, I., Bawa, S., Onwubiko, A. J., \& Onyowo, U. C. (2016). Exchange rate pass-through to inflation in Nigeria. CBN Journal of Applied Statistics, 7(1), 49-70.

Banerjee, A., \& Russell, B. (2001). The relationship between the mark-up and inflation in the G7 economies and Australia. Review of Economics and Statistics, 83(2), 377 - 387.

Campa, J. M., \& Goldberg, L. S. (2005). Exchange rate pass-through into import prices. The Review of Economics and Statistics, $87(4), 679-690$.

Engle, R., \& Granger, C. (1987). Co-integration and error correction: Representation. Estimation, and Testing, Econometrica, 55(2), $251-276$

Giles, D. (2013). ARDL models - part ii - bounds tests blog econometrics beat: Dave Giles' Blog. Retrieved from: http://davegiles.blogspot.co.uk/2013/06/ardl-models-part-iibounds-tests.html.

Hufner, F. P., \& Schroder, M. (2002). Exchange rate pass-through to consumer prices. A European Perspective' Centre for European Economic Research Discussion Paper No. 02-20.

Hyder, Z., \& Shah, S. (2004). Exchange rate pass-through to domestic prices in Pakistan. State Bank of Pakistan Working Paper No 5 .

Joyeux, R. (2001). How to deal with structural breaks in practical cointegration analysis. No 112, Research Papers, Macquarie University, Department of Economics.

Knetter, M. M. (1994). Is export price adjustment asymmetric?: Evaluating the market share and marketing bottlenecks hypotheses. Journal of International Money and Finance, 13(1), 55-70. Available at: https://doi.org/10.1016/02615606(94)90024-8.

Laflèche, T. (1997). The impact of exchange rate movements on consumer prices. Bank of Canada Review, 1996-1997 (Winter), 2132.

Mallick, S., \& Marques, H. H. (2010). Data frequency and exchange rate pass-through: Evidence from India's exports. International Review of Economics and Finance, 19 (1), 13-22. 
Menon, J. (1995). Exchange rate pass-through. Journal of Economic Surveys, 9(2), 197-231.

Oriavwote, V. E., \& Omojimite, B. O. (2012). An empirical investigation of exchange rate pass-through into domestic prices in Nigeria. European Journal of Economics, Finance and Administrative Sciences, 45(6), 61-72.

Oyinlola, M. A., \& Egwaikhide, F. O. (2011). Exchange rate pass-through to domestic prices in Nigeria: A dynamic investigation. Journal of Social Sciences, 6(20), 87-95.

Perron, P. (1989). The great crash, the oil price shock, and the unit root hypothesis. Econometrica, 57(6), 1361-1401.

Pesaran, M. H., \& Shin, Y. (1999). An autoregressive distributed lag modelling approach to cointegration analysis, chapter 11in Econometrics and Economic Theory in the 20th century the Ragnar Frisch Centennial Symposium, Strom S. (ed.). Cambridge University Press Cambridge.

Pesaran, M. H., Shin, Y., \& Smith, R. J. (1996). Testing for the 'existence of a long-run relationship. Cambridge Working Papers in Economics 9622, Faculty of Economics, University of Cambridge.

Pesaran., M. H., Shin, Y., \& Smith, R. J. (2001). Bounds testing approaches to the analysis of level relationships. Journal of Applied Econometrics, 16(3), 289-326. Available at: https://doi.org/10.1002/jae.616.

Sanusi, A. R. (2010). Exchange rate pass-through to consumer prices in Ghana: Evidence from structural vector auto-regression.

West African Journal of Monetary and Economic Integration, $10(1), 25-47$.

Taylor, J. B. (2000). Low inflation, pass-through, and the pricing power of firms. European Economic Review, 44(7), 1389-1408. Available at: https://doi.org/10.1016/s0014-2921(00)00037-4.

Usman, O., \& Musa, M. S. (2018). Revisiting exchange rate pass-through to consumer price inflation in Nigeria: A cointegrated vector autoregressive approach. Academic Journal of Economic Studies 4(1), 60-67.

Vogelsang, T., \& Perron, P. (1998). Additional tests for a unit root allowing for a break in the trend function at an unknown time. International Economic Review, 39(4), 1073-1100.

Zivot, E., \& Andrews, K. (1992). Further evidence on the great crash, the oil price shock, and the unit root hypothesis. Journal of Business and Economic Statistics, $10(10), 251-270$.

Zubair, A., George, O., \& Sanusi, A. R. (2013). Exchange rate pass-through to domestic prices in Nigeria: An empirical investigation. Central Bank of Nigeria Economic and Financial Review, 51(1), 1-27.

\section{Appendix:}

Appendix 1: Diagnostic test results

1.1 Quarterly Data

1.1.1Test for Serial Correlation

\begin{tabular}{l|l|l|l}
\hline \multicolumn{3}{l|}{ Breusch-Godfrey Serial Correlation LM Test: } & \\
\hline F-statistic & 1.134582 & Prob. F(2,93) & 0.3260 \\
\hline Obs*R-squared & 2.500937 & Prob. Chi-Square $(2)$ & 0.2864 \\
\hline
\end{tabular}

\subsection{Annual Data}

1.2.1 Test for Serial Correlation

\begin{tabular}{l|l|l|l}
\hline \multicolumn{3}{l|}{ Breusch-Godfrey Serial Correlation LM Test: } & \\
\hline F-statistic & 3.626165 & Prob. F(2,5) & 0.1064 \\
\hline Obs*R-squared & 16.57360 & Prob. Chi-Square $(2)$ & 0.0003 \\
\hline
\end{tabular}


1.2.2 The Gregory-Hansen Cointegration Test

\begin{tabular}{l|c}
\hline MODEL 2: Level Shift & \\
\hline ADF Procedure & -4.898888 \\
\hline t-stat & 0.000000 \\
\hline Lag & 1993 \\
\hline Break & -35.60960 \\
\hline Phillips Procedure & 1993 \\
\hline Za-stat & -5.203600 \\
\hline Za-break & 1993 \\
\hline Zt-stat &
\end{tabular}

\section{Appendix 2: Figures}

\section{1: Graphs of Variables In Level.}

Annual Series

Icpi

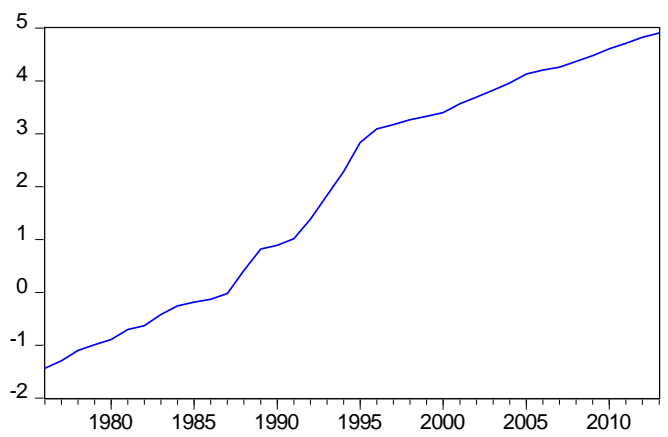

Ippi

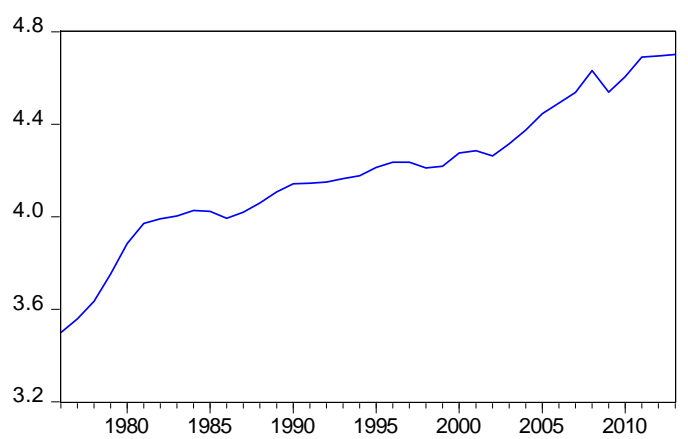

Igdp

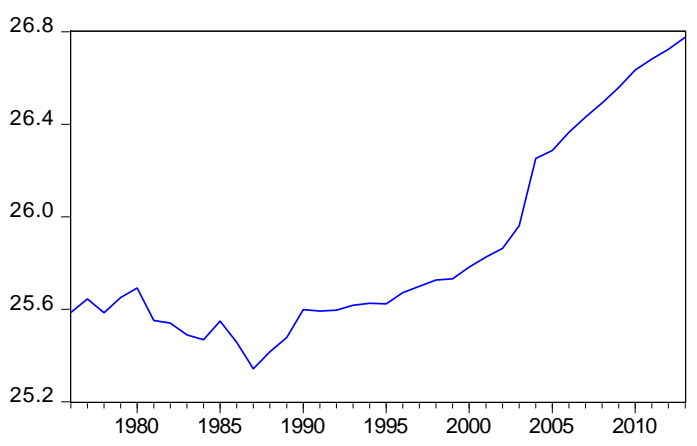

LER

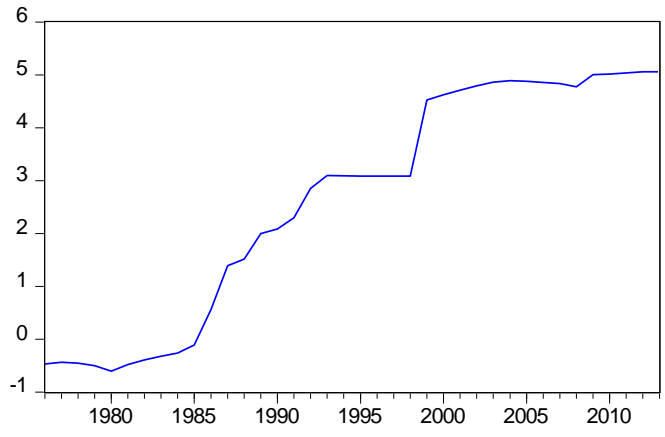

loilp

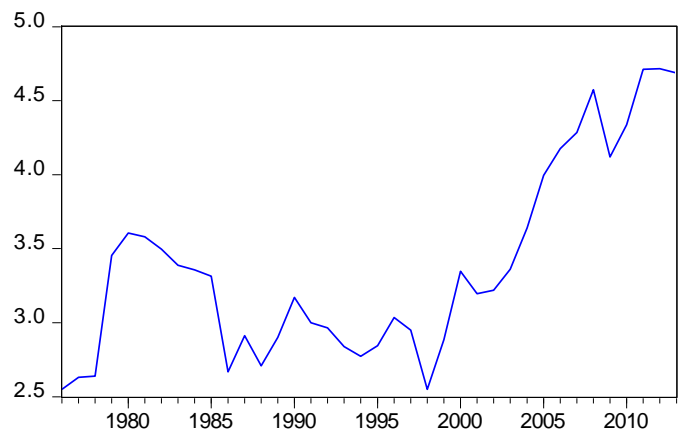


Quarterly Series

LCPI

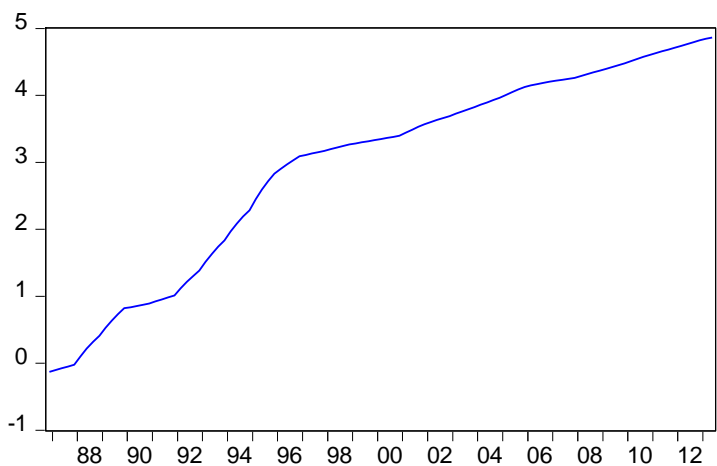

LPPI

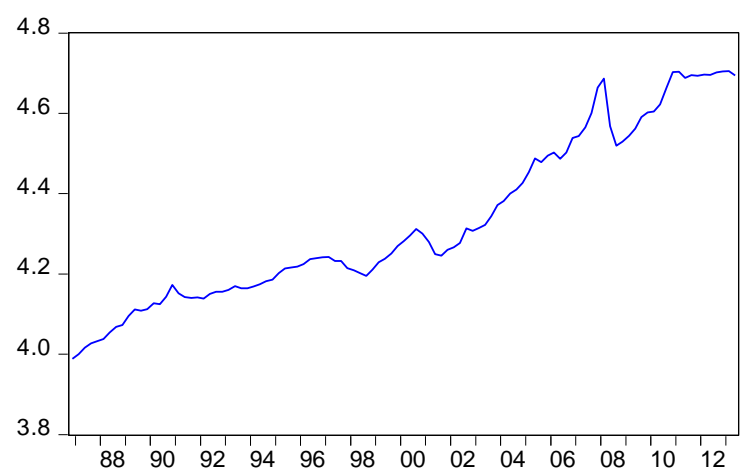

LGDP

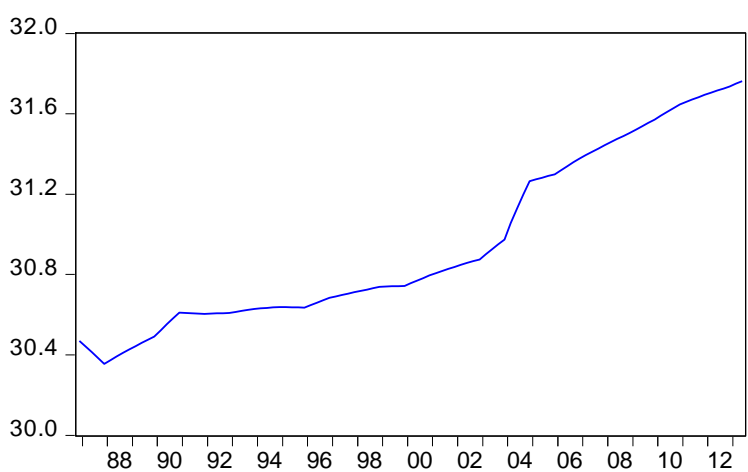

LER

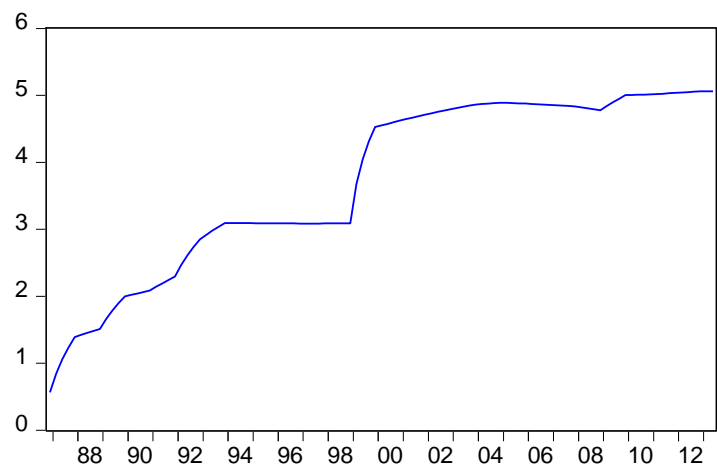

LOILP

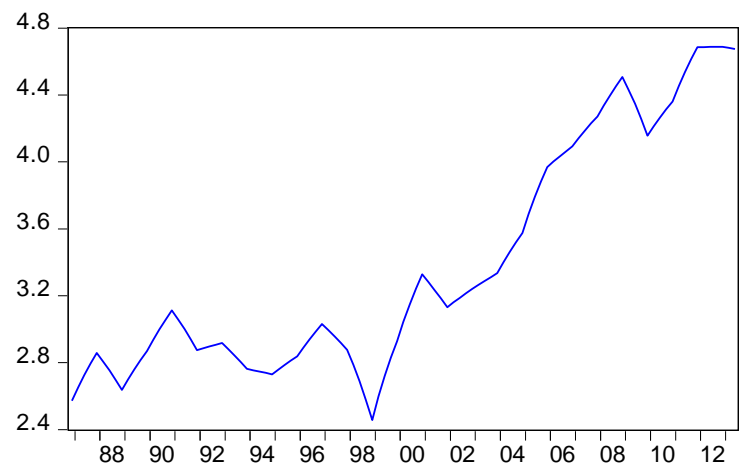

Views and opinions expressed in this article are the views and opinions of the author(s), International Journal of Business, Economics and Management shall not be responsible or answerable for any loss, damage or liability etc. caused in relation to/arising out of the use of the content. 